BBA 3573I

\title{
PURIFICATION AND PROPERTIES OF S-PROTEIN (HEMOPROTEIN 559) FROM HUMAN ERYTHROCYTES*
}

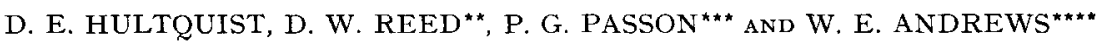

The Department of Biological Chemistry, The University of Michigan, Ann Arbor, Mich. 48 Io4 (U.S.A.)

(Received September 3rd, 1970)

I. A procedure employing mild conditions has been developed for purifying Sprotein (hemoprotein 559, erythrocyte), a protein present in the stromal fraction of human red blood cells. S-protein, solubilized by extracting the stroma of red blood cells with $\mathrm{pH} 8.2$ buffer, was purified by chromatography on DEAE-cellulose and Bio-Gel P-6o.

2. The oxidized and reduced forms of this protein show visible absorption spectra typical of $b$-type cytochromes. The oxidized form of the protein shows absorbance maxima at $4 \mathrm{I} 2,533$, and $565 \mathrm{~m} \mu$, and the dithionite-reduced spectrum shows maxima at 426,530 , and $559 \mathrm{~m} \mu$. The prosthetic group has been isolated and identified as protoheme IX by spectral and chromatographic techniques. The spectral properties of this protein differ from those of cytochrome $b_{5}$.

3. The reduced form of the protein binds $\mathrm{CO}$, and the resulting complex shows absorbance maxima at $42 \mathrm{I}, 54^{\circ}$, and $568 \mathrm{~m} \mu$. This spectrum, the CO-reduced minus reduced difference spectrum, and the spectra of the oxidized and reduced forms of the free protein are all indistinguishable from the corresponding spectra of hemoprotein $\mathrm{P}-420$, the altered form of the microsomal hydroxylase, hemoprotein $\mathrm{P}-45 \mathrm{O}$. The spectral properties, together with other physical properties, suggest that S-protein is $\mathrm{P}-420$ from erythrocytes.

\section{INTRODUCTION}

The insoluble or stromal fraction of red blood hemolysates contains, in addition to a number of colorless enzymes and structural proteins, a considerable amount of

* Parts of the data were taken from doctoral theses submitted to the Department of Bio. logical Chemistry, Rackham School of Graduate Study, The University of Michigan, by D.W.R. in I968 and by P.G.P. in 1970.

** Present address: Charles F. Kettering Research Laboratory, Yellow Springs, Ohio 45387 , U.S.A. ${ }^{\star \star \star}$ Present address: The Upjohn Co., Kalamazoo, Mich. 49oor, U.S.A. ${ }^{\star \star \star ~ P r e s e n t ~ a d ~}$ dress: Federal Water Quality Administration, Edison, N.J. 08817, U.S.A. 
colored protein. The amount of color associated with the stroma varies with the conditions of lysis and washing. This colored protein has often been referred to as "contaminating hemoglobin." In addition to the various forms of hemoglobin, however, the stroma contains a hemoprotein that has been called S-protein'. S-protein, solubilized by extracting stroma with slightly alkaline buffer, has been partially purified by repeated isoelectric precipitation at $\mathrm{pH} 5.5$ and partially characterized ${ }^{1-4}$. A study of the solubility, sedimentation, and electrophoretic properties has been made on a partially purified preparation ${ }^{5}$. In a more detailed study $y^{6,7}, \mathrm{~S}$-protein was shown to be a lipid-containing hemoprotein, of approx. 25000 mol. wt., which readily froms dimers. The spectral properties of the protein were similar to those of a $b$-type cytochrome. S-protein has been isolated from human, rabbit, and bovine red cells ${ }^{7}$. Attempts to further purify the protein by chromatographic techniques have been unsuccessful. The immunological properties of partially purified preparations of S-protein from a number of species have been reported ${ }^{8,9}$, but a more pure sample of human S-protein has been shown to have no or extremely little antigenicity to the rabbit?

In our laboratory, we have been unsuccessful in demonstrating a biological activity for S-protein isolated by isoelectric precipitation. This preparation failed to activate succinate-coenzyme $Q$ reductase activity in the reconstitution of mitochondrial electron transport $\mathbf{1 0}^{\mathbf{1 0}}$ and failed to serve as an electron acceptor for the reaction catalyzed by microsomal cytochrome $b_{5}$ reductase.

Since it is possible that the low $\mathrm{pH}$ employed during the isolation of S-protein modified its properties, we sought a milder procedure for isolating the hemoprotein before initiating an extensive search for its biological activity. In this paper, we report the purification of S-protein from human red blood cells by chromatographic procedures carried out at $\mathrm{pH} \mathrm{7.2,} \mathrm{and} \mathrm{draw} \mathrm{attention} \mathrm{to} \mathrm{the} \mathrm{similarities} \mathrm{between} \mathrm{the}$ properties of this protein and $\mathrm{P}-420$, the altered form of the microsomal hydroxylating enzyme, hemoprotein $\mathrm{P}-45^{\circ}$. Parts of this work have been reported in abstract form ${ }^{11}$.

MATERIALS AND METHODS

DEAE-cellulose was obtained from Fisher Chemical Co.; Bio-Gel P-60, I00-200 mesh, from Calbiochem; kerosene from Fisher Chemical Co. ; and 2,6-lutidine (95\%) from Eastman Organic Chemicals. Protoporphyrin dimethyl ester was prepared from red cells by the method of GRINSTEIN ${ }^{12}$.

Out-dated human red blood cells were generously supplied by St. Joseph's Mercy Hospital Blood Bank, Ann Arbor, Mich.; The University of Michigan Medical Center Blood Bank, Ann Arbor, Mich.; and the Bureau of Laboratories, Michigan Department of Public Health, Lansing, Mich. Cells were used and stored at $4^{\circ}$ in acidcitrate-dextrose Formula A (2.45 g glucose, $2.20 \mathrm{~g}$ citrate (trisodium salt), and $0.80 \mathrm{~g}$ citric acid in Ioo $\mathrm{ml}$ water) and were used within 3 weeks of their expiration date.

Disc electrophoresis was run at $\mathrm{pH} 9.5$ according to the method of Davis ${ }^{13}$. The lower gel concentration was $7.5 \%$ and the protein was applied in $40 \%$ sucrose. The gel was stained for protein with Coomassie brilliant blue by the method of Chrambach et al. ${ }^{14}$.

Sedimentation velocity analysis was carried out with a Spinco Model E Ultracentrifuge equipped with schlieren optics and a temperature control system. 
Visible absorption spectra were recorded at $25^{\circ}$ with a Cary Model I4 Spectrophotometer. Aliquots of a single solution of S-protein in $\mathrm{pH} 7.2$ potassium phosphate buffer $(0.2 \mathrm{M})$ were employed for all spectral studies. S-protein was reduced by adding a small amount of solid sodium dithionite. The reduced form of the protein was converted to the $\mathrm{CO}$ complex by subjecting the protein solution to one atmosphere of $\mathrm{CO}$ for one min. The pyridine hemochromes were formed by adding a few crystals of sodium dithionite to solutions of S-protein or its prosthetic group in $0.05 \mathrm{M} \mathrm{NaOH}-$ pyridine ( $5: \mathrm{I}$, by vol.)

The heme prosthetic group was extracted from the S-protein by slowly adding a cold aqueous solution of the protein to ro volumes of ethyl acetate-acetic acid (4:I, by vol.) at 4 . The colorless apoprotein was sedimented by centrifugation at $2000 \times g$ and discarded. Evaporation of the supernatant fraction to dryness, in vacuo at $25^{\circ}$, left the heme as a residue. Iron was removed from the heme by the method of MORELL et al. ${ }^{15}$, and the resulting porphyrins were converted to their methyl esters by treatment with methanol-sulfuric acid, according to the method of ScHWARTz et al. ${ }^{16}$. Samples were chromatographed in the ascending direction on Whatman No. I paper at room temperature. A mixture of 2,6-lutidine-water (10:7, by vol.) in an atmosphere of $\mathrm{NH}_{\mathbf{3}}{ }^{17}$ was employed for the chromatography of the heme. Chloroformkerosene (I3:20, by vol.) and $n$-propanol-kerosene $(\mathrm{I}: 5 \text {, by vol. })^{18}$ were employed for the chromatography of the porphyrin methyl esters.

\section{Hemolysis of red blood cells}

Out-dated human red cells were washed 3 times at $4^{\circ}$ by centrifuging a suspension of cells in $0.9 \% \mathrm{NaCl}$ solution at $5000 \times g$ for Io min and then decanting the buffy coat and supernatant fraction. Red cells were lysed by subjecting them to either hypotonic shock or to freezing and thawing. Lysis by freezing and thawing was accomplished by adding 3 volumes of water and 0.002 of a volume of toluene to the packed cells, and then rapidly freezing this suspension in a dry ice-acetone bath. The suspension was thawed and the procedure repeated. Hypotonic lysis was achieved by forcing (under air pressure) four volumes of cold water into the packed cells. The suspension obtained by either method of lysis was adjusted at $4^{\circ}$ to $\mathrm{pH} 6.0$ with $\mathrm{HCl}$, and the stroma was removed by centrifugation for $20 \mathrm{~min}$ at $10000 \times \mathrm{g}$.

\section{Solubilization of S-protein}

The stroma ( $50 \mathrm{ml}$ ) obtained from $375 \mathrm{ml}$ of packed cells was washed by suspending the material in $\mathrm{I} l$ of cold water and, after adjusting the $\mathrm{pH}$ to 6.0 , centrifuging at $I 7000 \times g$ for $20 \mathrm{~min}$. The stroma was then mixed with $250 \mathrm{ml}$ of cold water. S-protein was released from the stroma by adjusting the suspension to $\mathrm{pH} 8.2$ by the addition of $2.2 \mathrm{M}$ potassium glycinate, and then stirring for $20 \mathrm{~min}$ while maintaining the $\mathrm{pH}$ at 8.2. The insoluble fraction was removed by adjusting the suspension to $\mathrm{pH} 7.2$ with acetic acid and centrifuging at $17000 \times g$ for $20 \mathrm{~min}$. the extraction at $\mathrm{pH} 8.2$ was repeated twice using $250-\mathrm{ml}$ volumes of solution. The extracts were pooled and any additional precipitate was removed by centrifuging at I $7900 \times g$ for $20 \mathrm{~min}$.

\section{Purification of S-protein}

All purification steps were carried out at $4^{\circ}$ with potassium phosphate buffers 
prepared with distilled-deionized water. Purification was followed by measuring the ratio of the absorbance at $4 \mathrm{I} 2 \mathrm{~m} \mu$ to the absorbance at $280 \mathrm{~m} \mu$. Once hemoglobin had been completely removed, the total absorbance at $4 \mathrm{I} 2 \mathrm{~m} \mu\left(A_{\mathbf{4 1 2} \mathrm{m} \mu} \times \mathrm{ml}\right)$ was used as a measure of S-protein.

The extract of the stroma was charged at a rate of $3 \mathrm{ml} / \mathrm{min}$ onto a $4.7 \mathrm{~cm} \times$ $36 \mathrm{~cm}$ column of DEAE-cellulose previously equilibrated with $0.003 \mathrm{M}$ buffer $(\mathrm{pH}$ 7.2). The column was washed with $2 \mathrm{l}$ of the $0.003 \mathrm{M}$ buffer at a flcw rate of $3 \mathrm{ml} / \mathrm{min}$. The column was then eluted at $\mathrm{pH} 7.2$ with a linear gradient formed by placing $2.5 \mathrm{l}$ of $0.003 \mathrm{M}$ buffer in the mixing vessel and $2.5 \mathrm{l}$ of $0.2 \mathrm{M}$ buffer-I.O M KCl in the reservoir. The flow rate during elution was $1.8 \mathrm{ml} / \mathrm{min}$. The single colored fraction eluted from the column was identified as S-protein by its spectral properties.

The most concentrated part of this fraction (IO5 ml) was further purified. The solution was concentrated by lyophilization and then dialyzed for $\mathrm{I}$ h versus 21 of water. The sample was finally lyophilized to $8 \mathrm{ml}$ and placed on a $3.4 \mathrm{~cm} \times 106 \mathrm{~cm}$ Bio-Gel P-6o column previously equilibrated with $0.2 \mathrm{M}$ buffer ( $\mathrm{pH} 7.2$ ). The column was eluted with this buffer at a rate of $0.2 \mathrm{ml} / \mathrm{min}$.

\section{RESULTS}

The purification of S-protein from stroma obtained from cells that had been lysed by freezing and thawing is summarized in Table I. Most of the purification was achieved in the first three steps of the procedure: the preparation of stroma, the extraction of S-protein from the stroma, and chromatography on DEAE-cellulose. However, it was not possible to assess the degree of purification or the yield in these steps, since the presence of contaminating hemoglobin made quantitation of S-protein impossible.

A single colored fraction was eluted from the DEAE-cellulose column by the linear salt gradient, and only one peak was eluted from the P-6o column. Using the total $4 \mathrm{I} 2 \mathrm{~m} \mu$ absorbance $\left(A_{412} \mathrm{~m} \mu \times \mathrm{ml}\right)$ in the fraction eluted from the DEAEcellulose column as a measure of S-protein, a yield of 1300 absorbance units was obtained from $375 \mathrm{ml}$ of packed cells that had been lysed by the freezing and thawing method. In comparison, a yield of 836 absorbance units $\left(A_{412} \mathrm{~m} \mu \times \mathrm{ml}\right)$ was obtained from the same volume of cells lysed by hypotonic shock. Assuming a molar extinction at $4 \mathrm{I} 2 \mathrm{~m} \mu$ of $\mathrm{I} 24 \mathrm{~cm}^{2} \cdot \mathrm{mmole}^{-1}$ (see ref. I9) these yields correspond to I0.5 and 6.7 $\mu$ moles, respectively.

The most highly purified fraction of S-protein showed a $A_{412 \mathrm{~m} \mu} / A_{280 \mathrm{~m} \mu}$ ratio of 2.29. Electrophoresis of this sample on disc gel columns showed the presence of several contaminating proteins. The presence of a minor, more rapidly sedimenting component was demonstrated when this same sample was subjected to ultracentrifugation at $\mathrm{pH} 7.2$ in $0.2 \mathrm{M}$ potassium phosphate or $0.02 \mathrm{M}$ Tris-- $\mathrm{HCl}$ buffers, or at $\mathrm{pH}$ 8.2 in I.o M Tris-HCl buffer.

The visible absorbance spectrum of purified S-protein is shown in Fig. I. The spectra of the reduced form of S-protein and the CO complex of the reduced form are shown in Fig. 2. The reduced minus oxidized difference spectrum is shown in Fig. 3 and the CO-reduced minus reduced difference spectrum in Fig. 4.

Both the heme prosthetic group, obtained by extracting S-protein with nonpolar solvent under acidic conditions, and the intact protein formed pyridine hemo- 

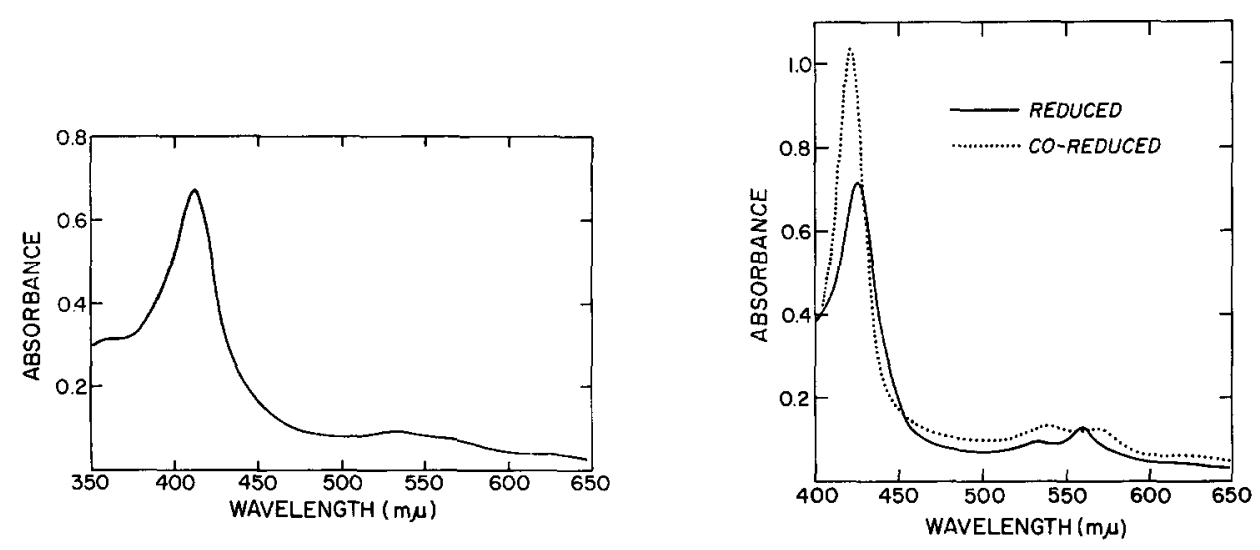

Fig. I. Visible absorbance spectrum of the isolated form of S-protein. The spectrum of a diluted solution of the purified sample was observed in $0.2 \mathrm{M}$ potassium phosphate buffer ( $\mathrm{pH} 7.2)$.

Fig. 2. Visible absorbance spectra of the reduced form of S-protein and the CO complex of the reduced form. Samples were reduced by the addition of a few crystals of sodium dithionite. The CO complex was formed anaerobically in the presence of $\mathbf{I}$ atm of CO. The sample and conditions are those described in Fig. $\mathbf{I}$.

chromes that were indistinguishable from the pyridine hemochrome of protoheme IX. These three complexes showed absorbance maxima at $4 \mathrm{I} 8,523$, and $55^{6} \mathrm{~m} \mu$. The heme of S-protein and protoheme IX migrated with the same $R_{F}(0.73)$ when chromatographed on paper in the lutidine-water solvent.

The porphyrin derived from the prosthetic group of S-protein and the methyl ester of this porphyrin showed visible absorbance spectra in chloroform, methanol, and $90 \%$ formic acid that could not be distinguished from the corresponding spectra of protoporphyrin dimethyl ester. The methyl esters of the porphyrin derived from S-protein comigrated with the methyl ester of protoporphyrin when chromatographed in the chloroform-kerosene and $n$-propanol-kerosene systems.
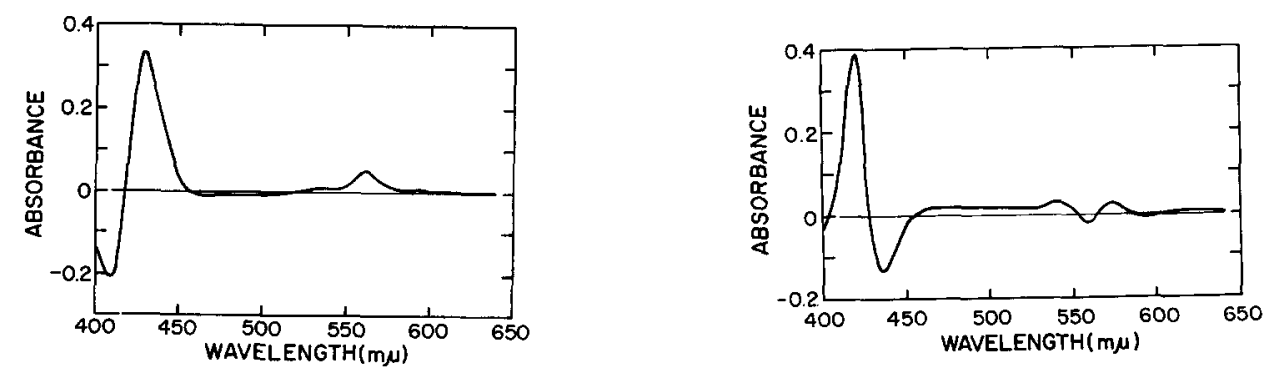

Fig. 3. Reduced S-protein minus oxidized S-protein difference spectrum. The sample and conditions are those described in Fig. 2.

Fig. 4. CO complex of reduced S-protein minus reduced S-protein difference spectrum. The sample and conditions are those described in Fig. 2. 


\section{DISCUSSION}

The isolation of S-protein from the insoluble stromal fraction of human red blood cells confirms the results of earlier studies that S-protein is a component of the membrane fraction of red cell hemolysates and, presumably, of intact cells. This conclusion is supported by our failure to detect S-protein in the supernatant fraction obtained from red cells by the procedure involving hypotonic lysis, adjustment of the $\mathrm{pH}$ to 6.0 , and centrifugation. Whereas S-protein remains tightly bound to stroma in buffers of low ionic strength at $\mathrm{pH} 6.0$, the protein is readily extracted from the stroma by buffers of $\mathrm{pH} 8.2$ and to a smaller extent by buffers of $\mathrm{pH} 7.2$. S-protein is effectively extracted at $\mathrm{pH} 7.2$ by I M LiCl.

Large losses of S-protein occurred when ammonium sulfate precipitation and subsequent dialysis were used to concentrate the protein. Moreover, recovery of hemoprotein from Bio-Gel columns was poor when low ionic strength buffers were employed for the chromatography. These losses might have resulted from dissociation of the heme from the protein or from aggregation and subsequent precipitation of the protein. To avoid these losses, concentration was accomplished by lyophilization, and buffers of relatively high ionic strength were employed for the Bio-Gel chromatography.

In the purification procedure described in this paper, we have attempted to minimize the possibility of protein modification. In contrast to the previous isolations of S-protein, this procedure involves chromatographic methods rather than isoelectric precipitation at low $\mathrm{pH}$. In the present procedure, the fractions were maintained at $\mathrm{pH} 7.2$ throughout, except for a short period of time at $\mathrm{pH} 6.0$ during the preparation of stroma and at $\mathrm{pH} 8.2$ during the solubilization of the S-protein. However, there is no assurance that the protein isolated by this procedure is in its native form; in fact, as with other proteins that are bound to membranes, the solubilization might be expected to result in marked changes in biological activity as well as in physical properties. It is of interest that the spectral properties of this preparation are indistinguishable from the corresponding spectra of S-protein isolated in this laboratory by isoelectric precipitation.

S-protein has now been purified and characterized sufficiently to establish that it is distinct from all other proteins of the human red cell, and that it does not appear

\section{TABLE I}

PURIFICATION OF S-PROTEIN FROM HUMAN ERYTHROCYTES

The isolation was carried out on $\mathrm{r}_{5} \mathrm{O} \mathrm{ml}$ of stroma obtained by freezing and thawing $375 \mathrm{ml}$ of stored human red blood cells.

\begin{tabular}{|c|c|c|c|c|}
\hline Fraction & $\begin{array}{l}\text { Vol. } \\
(m l)\end{array}$ & $A_{280} m \mu$ & $A_{412} m \mu$ & $\begin{array}{l}\text { Total } A_{412} m \mu \\
\left(A_{412} m \mu \times m l\right)\end{array}$ \\
\hline Stromal extract & 605 & 10.2 & I9.5 & I I 800 \\
\hline DEAE-cellulose eluate & 905 & I. 4 I & I. 44 & I300 \\
\hline Bio-Gel P-6o eluate & 30 & 3.26 & 6.56 & $197^{*}$ \\
\hline
\end{tabular}

* Only $21.5 \%$ of the S-protein fraction eluted from the DEAE-cellulose column was subsequently chromatographed on the Bio-Gel P-6o column.

Biochim. Biophys. Acta, 229 (I97I) 33-4I 
to correspond to a more native or less native form of some previously characterized red cell protein. These studies establish that S-protein is a hemoprotein with protoheme IX as its prosthetic group and with spectral properties characteristic of $b$-type cytochromes. On the basis of spectral properties, S-protein should be named "hemoprotein 559, erythrocyte." The observed properties of S-protein distinguish it from an erythrocyte protein ${ }^{20,21}$ which has been characterized as a low-field type hemoprotein with a unique, formyl-containing heme prosthetic group ${ }^{22}$. The spectral properties of the oxidized form, the reduced form, and the CO complex of the reduced form distinguish S-protein from the many forms of hemoglobin, from catalase, and from a cytochrome $b_{5}$-type protein that has been isolated from the supernatant fraction of red blood cell hemolysates ${ }^{23}$. A number of other properties also distinguish S-protein from all other proteins of the human red cell. Solubility properties, the presence of lipid, the molecular weight of approx. 25000 at $\mathrm{pH} 8$ in buffers of low ionic strength, and the dimerization reaction that occurs at low $\mathrm{pH}$ and high ionic strength have all been reported previously for the protein purified by isoelectric precipitation ${ }^{7}$; these findings have been confirmed in our laboratory. Furthermore, we have shown that the S-protein prepared by isoelectric precipization possesses an electron paramagnetic resonance spectrum which differs from that of the known erythrocyte hemoproteins.

\section{TABLE II}

SUMMARY OF VISIbLE SPECTRAL PROPERTIES OF S-PROTEIN AND P-420

For experimental details see Figs. I and 2.

\begin{tabular}{|c|c|c|c|c|c|c|c|c|}
\hline \multirow[t]{2}{*}{ Form } & \multicolumn{8}{|c|}{ Absorbance maxima (mu) } \\
\hline & \multicolumn{5}{|c|}{$S$-protein } & \multicolumn{3}{|c|}{$P-42 o^{19,24}$} \\
\hline Oxidized & $(360)$ & 412 & 533 & & $(360)$ & $4^{1} 4$ & 535 & \\
\hline Reduced & & 426 & $53 \mathrm{I}$ & 559 & & 426 & $53^{\circ}$ & 559 \\
\hline CO-reduced & & $42 \mathrm{I}$ & $54^{\circ}$ & 568 & & 421 & $53^{8}$ & 565 \\
\hline Reduced minus oxidized & & 429 & 530 & 559 & & 427 & 530 & 560 \\
\hline CO-reduced minus reduced & & 420 & $54 I$ & 573 & & 420 & $54^{\circ}$ & 575 \\
\hline
\end{tabular}

The spectral properties of S-protein do correspond, however, to those of $\mathrm{P}-420^{19,24}$, the altered and solubilized form of the hydroxylase, hemoprotein $\mathrm{P}-45 \mathrm{O}$, which has been detected in microsomes, adrenal mitochondria, and microorganisms. The spectra of the oxidized and reduced forms and the reduced minus oxidized difference spectra presented in Figs. I-3 are indistinguishable from spectra reported for $\mathrm{P}-420$. P-420, like S-protein, binds carbon monoxide in its reduced form to give a spectrum with a Soret peak at $42 \mathrm{I} \mathrm{m} \mu$. The spectrum of the CO complex of the reduced form of $\mathrm{P}-420$ and the $\mathrm{CO}$-reduced minus reduced difference spectrum are very similar to the spectra of S-protein shown in Figs. 2 and 4 . The similarity of the wavelengths of maximum absorbance for the various spectra of the two proteins are shown in Table II. The spectral changes resulting from changing the $\mathrm{pH}$ of the S-protein solution are similar to those that have been reported for liver microsomal $\mathrm{P}-420$. In the case of each protein, increasing the $\mathrm{pH}$ of the solutions from 7.0 to 9.0 increases the extinctions and sharpens the absorbance maxima of the reduced form, and decreases the extinction and broadens the Soret peak of the oxidized form. 
In addition to these spectral properties, S-protein has a number of other properties $^{7}$ similar to those reported for $\mathrm{P}-420^{19,24,25}$. Both proteins are present in cells in a membrane-bound form. In each case, solubilization yields a lipid-containing protein with a heme prosthetic group. Both are relatively low molecular weight proteins which aggregate, and finally precipitate, as the $\mathrm{pH}$ is gradually lowered from 8.o to 5.5. Both proteins can be reduced with dithionite, and the resulting reduced forms are rapidly autoxidized. Each of the above findings has been confirmed for S-protein in our laboratory. The spectral and chromatographic studies of the present investigation establish that the prosthetic group of S-protein, like that of $\mathrm{P}-420$, is protoheme IX. We have also shown that S-protein, like $\mathrm{P}-420^{19}$, does not serve as an electron acceptor for liver microsomal cytochrome $b_{5}$ reductase.

The similarities between the properties of S-protein and $\mathrm{P}-420$ suggest that S-protein may be the altered form of a red cell hydroxylase. Such an enzyme might be functional in the mature erythrocyte, or it might be functional only in the reticulocyte before maturation occurs. The fact that hemoprotein P-45o is found in the microsomal fraction of other tissues, suggests that a microsomal hydroxylase is present in reticulocytes. The loss of the endoplasmic reticulum during mammalian red blood cell maturation, might result in degradation of this hydroxylase to $\mathrm{S}$ protein which could then become associated with the stromal fraction of the cell.

\section{ACKNOWLEDGEMENTS}

The authors wish to thank Dr. Charles Carr and Dr. William Peterson for providing us with their method of purification and the results of their studies. We acknowledge the skillful technical assistance of Mr. Stephen Hansmire.

The third author was a predoctoral trainee of U.S. Public Health Service Grant GM-oor87.

This investigation was supported in part by Grants ORA-36608 and NFR-8 from The University of Michigan and by Grant AM-09250 from the U.S. Public Health Service.

\section{REFERENCES}

I M. Moskowitz, W. B. Dandliker, M. Calvin and R. Evans, J. Immunol., 65 (1950) $3^{8} 3$.

2 M. Calvin, R. S. Evans, V. Behrendt and G. Calvin, Proc. Soc. Expll. Biol. Med., 6i (1946) 416.

3 M. Moskowitz and M. Calvin, Exptl. Cell Res, 3 (I952) 33.

4 A. Haut, G. R. Tudhope, G. E. Cartwright and M. M. Wintrobe, J. Clin. Invest., 4I (I962) 579 .

5 C. Howe, J. Immunol., 66 (I95I) 9.

6 W. J. Peterson and C. W. Carr, J. Cell Biol., 2, 23 (1964) 72A.

7 W. J. Peterson, Studies on a Hemoprotein of the Erythrocyte, Thesis, University of Minnesota, Minneapolis, Minn., I963.

8 G. Vulpis, N. Vulpis ANd C. Santoro, Nouvelle Rev. Frang. Hematol., 4 (I964) 645.

9 G. Vulpis, N. Vulpis and C. Santoro, Vox Sanguinis, Io (1965) ror.

io A. Bruni and E. Racker, J. Biol. Chem., 243 (I968) 962.

I I P. G. PAsson ANd D. E. Hultouist, Federation Proc., 29 (1970) 732.

I 2 M. Grinstein, J. Biol. Chem., I67 (I947) 5I5.

I3 B. J. Davis, Ann. N.Y. Acad. Sci., I2I (1964) $40_{4}$.

I4 A. Chrambach, R. A. Reisfeld, M. Wyckoff and J. Zaccari, Anal. Biochem., 20 (I967) I50.

I 5 D. B. Morell, J. M. Barrett and P. S. Clezy, Biochem. J., 78 (I96I) 793 .

i6 S. Schwartz, V. Hawhinson, S. Cohen and C. J. Watson, J. Biol. Chem., I68 (I947) I33.

Biochim. Biophys. Acta, 229!(197I) 33-4I 
I 7 T. C. Chu and E, J. Chu, J. Biol. Chem., 2 I 2 (I955) I.

I 8 T. C. Chu, A. A. Green and E. J. Chu, J. Biol. Chem., I9o (I95I) 643.

I9 T. Omura and R. Sato, J. Biol. Chem., 239 (I964) 2379.

2O M. MORRISON, Nature, I89 (I96I) 765 .

2 I M. Morrison, D. W. Reed and D. E. Hultquist, Biochim. Biophys. Acta, 2 I 4 (I970) 389.

22 D. W. Reed and D. E. Hultguist, Federation Proc., 26 (1967) 823.

23 D. E. Hultquist, D. W. Reed and P. G. Passon, Federation Proc., 28 (ig69) 862.

24 T. Omura and R. Sato, J. Biol. Chem., 239 (1964) 2370.

25 T. Omura and R. Sato, Biochim. Biophys. Acta, 7 I (I963) 224.

Biochim. Biophys. Acta, 229 (197I) 33-4I 